\title{
УДК 622:624:550.82
}

\section{SYSTEMIC DEVELOPMENT OF KYIV UNDERGROUND SPACE. PRIORITY TASKS AND ELIMINATION OF POSSIBLE RISKS СИСТЕМНИЙ РОЗВИТОК ПІДЗЕМНОГО ПРОСТОРУ КИЄВА. ПРИОРИТЕТНІ ЗАВДАННЯ ТА УСУНЕННЯ МОЖЛИВИХ РИЗИКІВ}

Antonenko I.V. / Антоненко И.В. sen. lecturer / cm. преподаватель ORCID: 0000-0002-5762-1401

Kyiv National University of Technology and Design, Kiev, Nemirovich-Danchenko 2, 01011 Киевский национальный университет технологий и дизайна, Киев, Немировича-Данченко, 2, 01011

Анотація. У статті розглянуто питання освоєння підземного простору у Києві. Виявлено переваги та можливі аспекти проблематики, які гальмують планування та будівництво сучасного «підземного украӥнського міста». Аналізується використання комплексного підходу для позитивної зміни існуючої ситуації.

Ключові слова: підземний простір, мегаполіс, комплексний підхід, сталий розвиток, прогнозування, концептуальні моделі.

\section{Вступ.}

Науково-технічна проблема освоєння підземного простору має комплексний характер. До іiі вирішення залучено широке коло вчених та фахівців, насамперед архітекторів, інженерів, у тому числі гірничих, будівельників, юристів, психологів, фахівців 3 безпеки життєдіяльності. Майбутня урбанізація підземного простору в мегаполісах - це необхідність, спричинена їх перенаселенням та неможливістю подальшого розширення.

У історії поселень людей є досвід життя у печерах, тому варіант розвитку міста «вглиб» не можна вважати новим. Проте, у давнину люди використовували природні печери. Сучасні ж технології та матеріали привносять у освоєння підземного простору нові можливості та аспекти, які мають бути ретельно вивчені, зокрема щодо оцінки потенційних небезпек та ризиків освоєння підземного простору. Повна оцінка витрат та отриманих переваг має відбуватися протягом життєвого циклу підземних об'єктів, тобто економічна оцінка має враховувати довгострокову перспективу, а також екологічні та соціальні аспекти розвитку міст. Стійкий розвиток систем пропорційний до повноти інформації щодо об'єктивних переваг, недоліків, потенційних небезпек та ризиків об'єктів підземної інфраструктури та їх взаємодії 3 мегасистемами великого міста, що потребує ефективного інструментарію прогнозування та моделювання систем високої складності, використання методів системного підходу. Це дасть інвесторам та міським державним адміністраціям ефективний інструмент управління ризиками та інвестиціями під час освоєння підземного простору мегаполісів [1, с. 174].

\section{Основний текст.}

Абсолютно апробованих методів проектування та технологій будівництва гігантських підземних будівель поки що немає. Однак, враховуючи, що для подібних споруд відбиратимуться монолітні ділянки масивів гірських порід 
високої міцності, швидше за все, використовуватимуться технології проведення вертикальних стволів великого діаметра та глибини. Не кожен масив гірських порід придатний для реалізації таких проектів. На думку геологів, найбільш придатними для будівництва підземних міст є Канада, Швеція, Норвегія, Південна Африка та Китай.
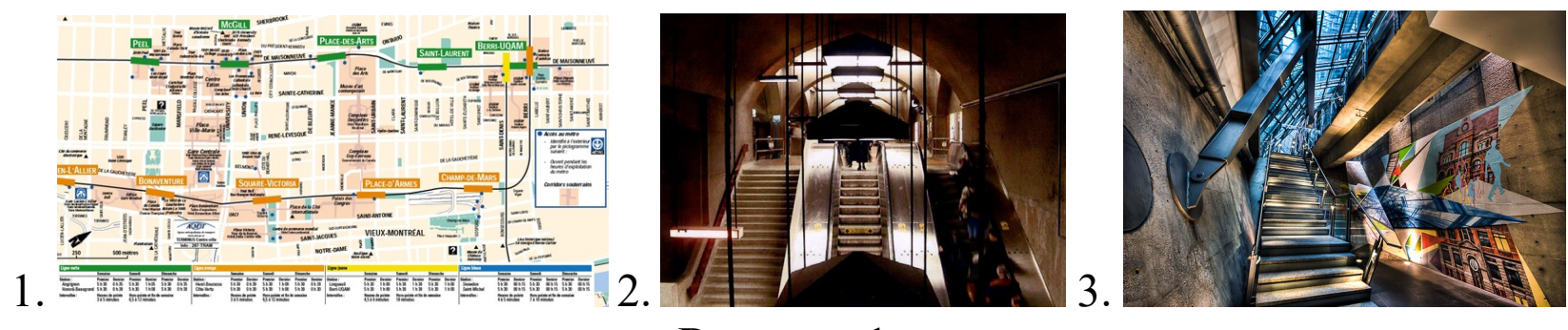

Рисунок 1.

\section{1. Підземна багатофункціональна пішохідна система Монреалю - «RESO»;} 2. Фрагмент інтер'єру підземного комплексу Монреаль; 3. Фреска на честь 20-го ювілею «World Trade Centre»

Джерело: https://undergroundexpert.info/opyt-podzemnogo-stroitelstva/realizovannyeproekty/stroitelstvo-podzemnogo-goroda-monrealya-reso/ [9]

Підземна пішохідна мережа Монреаля (Канада) вважається однією 3 найбільших у світі (рис. 1). Маючи понад 30 км у довжину, вона почала створюватися в 1962 р. і після відкриття в 1966 р. нової лінії метро набула особливого розвитку, завдяки тому, що дві iї головні паралельні лінії були розділені відстанню всього 800 м. Пішохідна мережа загальною площею 300 тис. м2 пов'язує станції цих ліній з розміщеними між ними 1600 магазинами, 200 ресторанами, банками, офісами, підземними парковками [7, стор 90].

Що стосується конфігурації підземних хмарочосів, це залежить від їх «висоти» i властивостей міцності породних масивів: в скельних можлива i пірамідальна, і прямокутна форми. У слабких, особливо при великій глибині, краще кругла форма, найбільш стійка до зовнішніх впливів. Фактично, це будинок, споруджений у шахтному стволі великого діаметра, як, наприклад, у підземному комплексі Сеула. При цьому можливий варіант будівлі атріумного типу, принаймні у верхній житловій його частині [2].
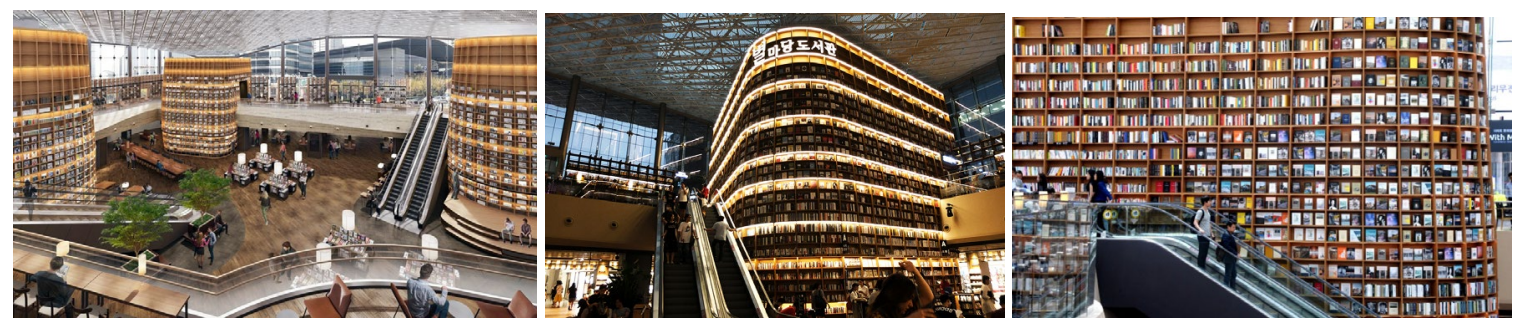

Рисунок 2. Торговий центр Сеула (Південна Корея) «СOEX Mall»

Джерело: https://undergroundexpert.info/opyt-podzemnogo-stroitelstva/realizovannyeproekty/stroitelstvo-podzemnogo-goroda-monrealya-reso/ [8] 
Найбільший підземний торговий центр Азії «COEX Mall» (рис. 2), розташований у Корейському Сеулі, має також у своєму складі унікальну бібліотеку «Starfield Library» (відкрита в 2017 р.), фонд якої налічує понад 50 000 назв і займає площу в 2800 м2. Бібліотека належить компанії "Shinsegae", була відкрита з метою залучення більшої кількості відвідувачів до підземного комплексу, в ній приблизно 200 сидячих місць.

Чи розвиватиметься Київ углиб поки що не цілком зрозуміло. Найвідоміший освоєний підземний простір, торговий центр «Globus» (рис. 3), був розроблений у 70-х роках XX ст. і реалізований лише у 2001 р. Скептичне ставлення щодо бажання городян спускатися під землю долалося самою конструкцією центру та дизайном підземних просторів - високими стелями та атріумом зі скляним куполом, через який під землю надходило денне світло. Грамотне проектування та якісне будівництво даного торгового центру зняло й інші важливі питання, що зазвичай виникають з боку орендарів - доставки товару, безпеки у разі пожежі та інших подій [3, с. 209].
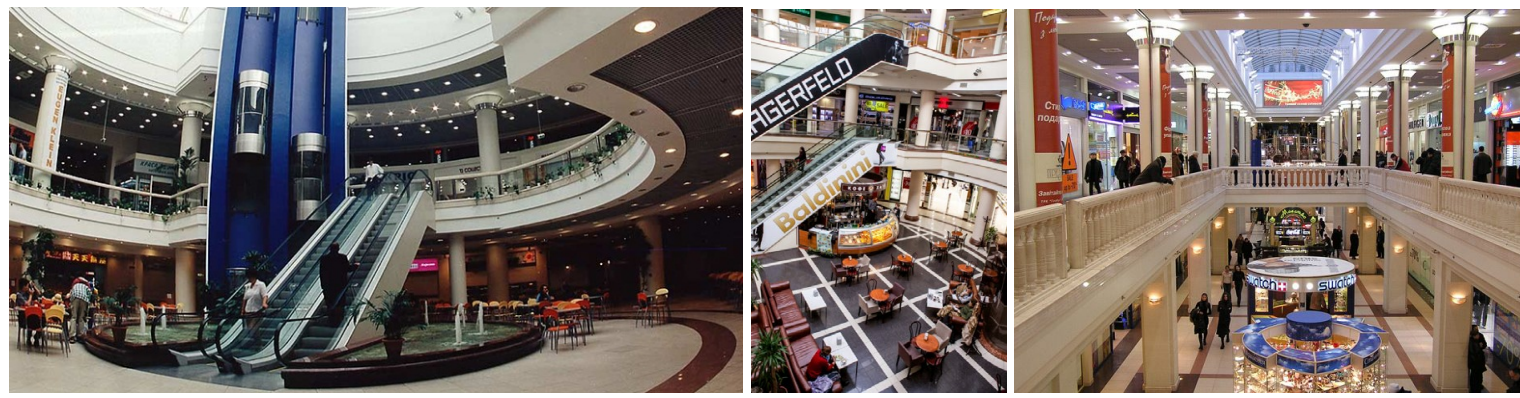

Рисунок 3. Внутрішні простори торгового центру «Globus» у Кисві

Джерело: https://rau.ua/ru/news/6261-petr-khoroshok-globus-glavnaya-biznes-tsel-na-2016-godsdelat-uroven-vakantnosti-ne-vyshe-1-6-2/ [10]

Однак багатьом людям, як і раніше, психологічно важко подолати негативне сприйняття «підземелля». Містобудівниками вже не раз висувалося питання необхідності наявності концепції розвитку Києва - вглиб, вшир, угору, бачення того, яке місто ми хочемо побудувати. Не виключено, що столиця України може складатися не зі спальних мікрорайонів, промислових зон та бізнес-центрів, а із кількох самодостатніх районів, у кожному з яких $є$ все необхідне для різноманітних видів роботи та відпочинку. Тоді з Троєщини, населення якої за чисельністю більше за обласний центр Житомир, не треба буде їхати на роботу через весь Київ. Подібні принципи розвитку міських територій (іх називають екологічним девелопментом) стають все більш популярними у світі, вони значно зменшують внутрішньоміські транспортні потоки та покращують соціальну та екологічну ситуацію у місті. А можливо, доцільніше будувати мегаполіс і переселяти більшу частину населення країни в одне місто, і розвивати міста в регіонах, як зробили колись у соціалістичній Чехословаччині, стимулювавши інтенсивний розвиток провінції системою пільг. Але за будь-якого варіанта розвитку місто має бути безпечним середовищем проживання для всіх мешканців. Тому наука має передувати процесу будівництва та відстежувати експлуатаційний період. 
При виборі варіанта розвитку вглиб слід враховувати, що Київ - історичне місто, і що печери та порожнечі завжди були факторами, що ведуть до деформацій, зокрема руйнівних. Наприклад, наприкінці 1940-х років у Кирилівській церкві почали утворюватися тріщини, що загрожували цілісності будівлі. У ході досліджень під церквою було виявлено підземні ходи, які довелося бутувати, щоб зупинити осідання будівлі. Риття котлованів (особливо якщо воно ведеться технічно неправильно) також призводить до пошкодження будівель, що знаходяться в безпосередній близькості від будівництва. Котлован зменшує напруги в грунтах під сусідніми будинками, i в певних умовах може початися опливання грунтів у котлован, а потім і деформація будівель. Так постраждала будівля Інституту геологічних наук НАН України на вулиці Олеся Гончара також від викопаного поблизу котловану. Коли в процесі будівництва фітнес-центру біля Софійського собору було вирито котлован, одразу впала частина огорожі собору, а на значній площі території храму, за будівлею бурси, відбулося осідання грунту [4].

Наукове обгрунтування будівництва нових будівель та охорони пам'яток історії та архітектури, фонової забудови - мінімізує помилки, а можливо виключить їх повністю. Необхідний науково-технічний контроль міського будівництва. Це - питання безпеки не лише міста, а й держави. Реновація та музеєфікація наявних підземних споруд культурно-історичного значення $\epsilon$ невід'ємною складовою розвитку підземної урбаністики. Важливим напрямом також можна назвати використання підземних споруд, які втратили первісне функціональне навантаження за новим призначенням. Цікавим підходом може стати використання принципу «майбутньої користі» вже на етапі проектування нових підземних об'єктів 3 передбаченням можливої зміни їх функцій відповідно до розвитку потреб суспільства [1, с. 174].

Основну роль при руйнуванні будівель відіграє гідрогеологічний фактор. Через порушення природного режиму поверхневих та підземних вод та подальших деформацій грунтових основ практично всі старі будівлі в тій чи іншій мірі пошкоджені. Біля будівель часто відбувається акумуляція поверхневих стоків. Тоді вода дуже швидко просочується до фундаментів i перезволожує грунти, що також може спричинити деформацію грунтів та будівель. Нерідко під землею утворюється верховодка (тимчасовий водоносний горизонт, який утримується грунтами). Верховодка має велике поширення, наприклад, нею заповнено всю центральну ділянку Подолу, але лише нещодавно гідрогеологи навчилися іiі досліджувати. Місто, особливо його історична частина, перенасичене інженерними мережами, значна частина яких перебуває у незадовільному стані. За грубою оцінкою, близько $30 \%$ води, що протікає по комунікаціях, втрачається в грунті. Це суттєво впливає на підйом рівня грунтових вод. Коли приблизно рік тому в районі церкви Миколи Притиски, пам'ятки архітектури, фундаменти якої були підтоплені, замінили теплотрасу та водогін, рівень грунтових вод знизився майже на 2 метри [4].

Для покращення стратегічної координації розвитку підземної інфраструктури потрібне формування правової та адміністративної підтримки розвитку підземної урбаністики, зокрема створення відповідного 
адміністративного органу, спрямованого на розвиток міського підземного будівництва. Це забезпечить скоординоване планування підземного простору міста, підготовку необхідних будівельних норм та правил; надасть можливість збирання, архівування та доступу до відповідної інформації для оперативного прийняття рішень та виконання проектних робіт. Подібна координація може також призвести до покращення управління науково-дослідними інвестиціями, прискорить видачу дозвільних документів, забезпечить підтримку з боку держави та муніципальної адміністрації [1, с. 172].

Бажано більш глибоке розпізнання взаємних зв'язків між структурнофункціональними, економічними, технологічними та природними чинниками для планування «підземного міста» та його взаємодії з наземною (поверхневою) забудовою та інфраструктурою. Це вимагає розробки концептуальних моделей складних взаємовпливів між урбаністичними системами (людина та суспільство мегаполісу, природне та інженерне середовище, геобудівельна техніка та технологія, транспорт тощо) для розуміння взаємодії систем, зменшення ризиків та ефективного управління в умовах швидкого розвитку технологій, соціальних змін та очікувань. Для цього аналізу слід розглядати позитивні та негативні сценарії, оптимізуючи інтерфейси відповідно до термінів планувальних рішень [5, с. 34-46; 6, с. 92-98].

Доцільно звернути увагу на те, що рішення про підземні інфраструктурні проекти часом приймаються групами 3 конкуруючими економічними чи громадськими інтересами. Розробка стратегічних майстер-планів розвитку підземної урбаністики може зменшити гостроту конкурентних протистоянь, оскільки за планового створення розгалуженого «підземного міста» привабливих об'єктів вистачить для багатьох інвесторів, а затверджений стратегічний план стане гарантом регіонального розвитку для інвесторів.

Забезпечення сталого розвитку міста потребує міждисциплінарних зусиль протягом усього життєвого циклу міської інфраструктури. Сьогодні містобудівна наука зосереджена у будівельних університетах та наукових центрах, а будівництво підземних споруд - переважно у гірських та транспортних. У системі академічних наук міська тематика знаходиться на периферії таких дисциплін як географія, економіка, соціологія, філософія, що дуже ускладнює спроби формування універсальної теорії урбаністичного розвитку. Ефективне поєднання різних знань та підходів бачиться тут у можливостях сучасних методів ІТ-підтримки трансдисциплінарних досліджень, онтологічних моделях, прикладному системному аналізі.

Ефективність робіт значно збільшується, коли інженери-проектувальники підземних комплексів розуміють складні соціальні, економічні та екологічні фактори розвитку мегаполісу, а містобудівники мають реалістичні очікування щодо підземного простору та його можливостей. Врахування ризиків при екстремальних явищах (терористичні акти, військові дії, стихійні лиха, техногенні та екологічні катастрофи) може сприяти розширеному освоєнню підземного простору, менш вразливого до наслідків зазначених явищ. Тут слід передбачати та враховувати поведінку людини в умовах постійно мінливого міського середовища та відповідним чином створювати умови для розуміння 
мешканцями підвищеної безпеки підземних споруд у різних складних обставинах [1, с. 173].

\section{Завершення і висновки.}

Науково-технічна проблема освоєння підземного простору має комплексний характер. Це потребує ефективного інструментарію прогнозування та моделювання систем високої складності, використання методів системного підходу. Чи розвиватиметься Київ углиб поки що не цілком зрозуміло. Вже неодноразово виникало питання необхідності наявності концепції розвитку столиці. При виборі варіанта розвитку в глибину слід враховувати, що Київ - історичне місто, а підземні порожнечі завжди були факторами, що ведуть до деформацій. Також має враховуватися гідрогеологічний фактор, температура порід та грунтові води. Для вирішення проблем потрібний скоординований зв'язок усіх зацікавлених сторін i створення координуючої організації 3 розвитку підземної урбаністики. Забезпечення сталого розвитку міста потребує міждисциплінарних зусиль протягом усього життєвого циклу міської інфраструктури. Ефективне поєднання різних знань та підходів бачиться тут у можливостях сучасних методів ІТ-підтримки трансдисциплінарних досліджень, онтологічних моделях, прикладному системному аналізі та створенні умов для розуміння мешканцями підвищеної безпеки підземних споруд у різних складних обставинах.

Литература:

1. Гайко Г. І. Комплекс пріоритетних завдань для системного розвитку підземної урбаністики / Г. І. Гайко // Форум гірників - 2019: матеріали міжнар. наук.-техн. конф., 26-27 верес. 2019 р. До 120-річчя заснування Університету. Дніпро : Журфонд, 2019. - С. 171-175.

2. Картозия Б.А. Города уйдут под землю. - «Кот Шрёдингера» №4 (16), апрель 2016 г. - URL: http://kot.sh/statya/1796/goroda-uydut-pod-zemlyu

3. Тригуб Р. М. Роль споруд підземного простору в сучасному місті / Тригуб Р. М. // Сучасні технології та методи розрахунків у будівництві. Луцьк: 2019. - Том 1. - Номер 1. - С. 207-212.

4. Рибін В.Ф., старший науковий співробітник Інституту геологічних наук НАН України, гідрогеолог. - Архів видавничого дому «Commercial Property» №8 (216) 2021. - URL: https://commercialproperty.ua/cp-articles/alternativanazemnoy-torgovle/

5. Natalya D. Pankratova, Ilya A. Savchenko, Gennadiy I. Gayko, Victor G. Kravets. Evaluating Perspectives of Urban Underground Construction Using Modified Morphological Analysis Method// Journal of Automation and Information Sciences, 2018, Volume 50, Issue 10. - P. 34-46.

6. Haiko H.I., Savchenko I.O., Matviichuk I.O. Development of a morphological model for territorial development of underground city space// Naukovyi Visnyk NHU, 2019, № 3. - P. 92-98.

7. Kaufman L.L., Lisikov B.A. Underground structures. (2 volumes): Volume 2. Monographie. / Kaufman L.L., Lisikov B.A. - Donetsk, «Nord-Press», 2005. - 216 p.

8. Как библиотека создала невероятный трафик! - URL: http://wiahome.com 
9. Подземный город для пешеходов RESO. - URL: https://undergroundexpert.info/opyt-podzemnogo-stroitelstva/realizovannyeproekty/stroitelstvo-podzemnogo-goroda-monrealya-reso/

10. URL: https://rau.ua/ru/news/6261-petr-khoroshok-globus-glavnaya-biznestsel-na-2016-god-sdelat-uroven-vakantnosti-ne-vyshe-1-6-2/

Abstract. The article considers the development of underground space in Kiev. The advantages and possible aspects of the issues that hinder the planning and construction of a modern "underground Ukrainian city" are identified. The use of an integrated approach for positive change of the existing situation is analyzed.

Key words: underground space, metropolis, integrated approach, sustainable development, forecasting, conceptual models.

Статья отправлена: 17.11.2021 г.

Антоненко И.В. 